\title{
Investigation of Architect and Non-Architect Participants' Perceptual Evaluations on Different Period Mosque Facades
}

\section{H. Derya Arslan Kemal Yıldırım** Esin Gülşeker $^{* \star *}$}

\begin{abstract}
In architecture, perception based studies about building facades have become more popular. In recent studies, mostly residential buildings and business center type of buildings had been selected as target buildings. The lack of study of the perception of the facades of religious structures has created the basic motivation for this work. In the current study, the facade features of (Seljuk period, Ottoman period and Republic period) some important mosques from different periods were evaluated according to the adjective pairs of complexity, preference and impressiveness variables. Also, whether or not the general views of the mosques represent Islamic religion and their level of arousing curiosity were questioned. For this purpose, in the study, a total of 16 mosques were used. The results obtained from the participants as architect and non-architect are given. It is seen that the participant architects show a statistically more negative approach compared to those who are nonarchitects in the perceptual evaluations of the facades of the mosques for complexity variable. On the other hand, there was no statistically significant difference between the participants' evaluations of preference and impressiveness variables (at $\mathrm{p}<0.05$ level).
\end{abstract}

Keywords: Perception, Mosque, Architect, Non-Architects, Facade

*(Corresponding Author) Dr. Necmettin Erbakan University, Faculty of Engineering and Architecture, Department of Architecture, Konya,Turkey

E-mail: deryaarslan@konya.edu.tr

Orcid ID: http://orcid.org/0000-0001-77423405

**Prof. Dr. Gazi University, Faculty of Technical Education, Department of Furniture and Decoration, 06500 Besevler, Ankara, Turkey

E-mail: kemaly@gazi.edu.tr

Orcid ID: http://orcid.org/0000-0001-54471201

*** Architect, Necmettin Erbakan University, Faculty of Engineering and Architecture Department of Architecture, Konya, Turkey E-mail: esingulseker@gmail.com Orcid ID: http://orcid.org/0000-0001-54471201 


\section{INTRODUCTION}

The values that buildings represent in terms of architecture depend on many elements. The most important of these factors is the building facade. The meaning that the architect attributes to the building is often understood from the facade of the building. The urban space and the building facades consisting of vertical and horizontal components determining the limit of the building potentially reflect the character of the architect in many different dimensions. The building facades reflecting the architect's character also give information especially about the space that it bounds and the spirit of the city it is in. Krier (1993) defines the facades of buildings as the walls that limit the urban spaces where exterior turns into interior or the intersection (interpenetration) areas where the function changes whereas he classifies the facade as a membrane actually separating the spirit of the city and the spirit concealed at the essence of the building in a distinguishable way. The building facade can also be defined as an interface between the architectural space and the urban space.

By analyzing the architecture facade from different angles, it is possible to have important knowledge in architectural form. The building makes sense of itself through the dialogue between the facades and inside. The items on the facade often point to the beliefs, concepts, and ambitions of the architect that the architect wants to attribute to the building. According to Robert Venturi meaning to be assigned to the building facade is very important and if necessary, this meaning must be attributed to the facade by using non-architectural elements. Norman Foster, on the other hand, shows the facade more as a means of control and display.

Facade, which reveals the identity of the building, communicates with the environment, people through the signs it carries. The facade is read by a human through the eye, which is the most effective sense organ in the reception of an external stimulus of the human brain, and related visual perception. On the facade, all the secret and nonsecret codes the architect wants to give are perceived by the person within a short time and the meaning in architectural construction begins with the signs given by the structure, the primary indicator. The perception of human regarding the facade occurs by interaction with the facade, getting information as a result of this interaction and putting this information in his mind as a whole of experience and then using it. Baytin (1994) and Füeg (1981), state that an architect needs to know in advance what effect the vision will bring about and what reaction it will receive in order to be able to reflect what he or she wants to tell, to see what kind of impressions he or she will obtain 
from geometric forms and the architecture can only exist through the human that can perceive.

There are numerous studies in the literature that have become more popular in the last two decades in which the effects of building facades and the building interiors on people are evaluated. In these studies, the studies were conducted on how the physical properties of spaces affect people's perceptionbehavioral evaluations. In all of the studies, (Evans, 2003; Tsunetsugu et al., 2005; Küller, 2002; Kobayash and Sato, 1992; Noguchi and Sakaguchi, 1999 and Dunn and Hayes, 2000) associating the socio-emotional reactions of people with buildings and interiors, it has been seen that the physiological response of the human being is interrelated with the visual environment and space design.

In the studies on building facade and interior perception, mostly dependent variables were used such as preference, complexity and impressiveness variables. For example some researchers (Berlyne, 1974; Herzog ve Shier, 2000; Imamoglu, 2000; Stamps, 2003; Devlin and Nasar, 1989; Kaplan et al., 1972; Nasar, 1983; Akalın et al., 2009; Wohlwill, 1968 and Crozier, 1974) examined building visuals facade using the variable of complexity and preference.

In perceptual studies in literature, the comparison of age, gender, education level as well as architects and non-architects groups have been made. In the study conducted by Hershberger (1969) that entered the literature for the first time, the perception differences between architects and non-architects were examined. Later, various studies were carried out on the basis of this study (Hershberger ve Cass, 1974; Groat, 1982; Devlin \& Nasar, 1989; Nasar, 1989; Stamps, 1991; Imamoğlu 2000, Akalın et al., 2009). In the study carried out by Brown and Gifford (2001) to determine the perception differences between the designer and the user where the effect of social factors in perception is studied, it has been found that the education got creates differences in perception. Similarly, Gifford et al. $(2000,2002)$ examined in their study that architects, as compared to non-architects, have a different approach to aesthetic evaluations of building facades physically and emotionally. As a result, both groups were found to have different emotional evaluations on the building characters. The common result obtained from studies is that architects' evaluation is more critical than non-architect groups.

In the studies conducted on the perception of building facades, mostly residential buildings and business centre type of buildings were selected as examples. In particular, the lack of study of the 
perception of the facades of religious structures has created the basic motivation for this work. In accordance with this purpose, it has been aimed to determine in which direction the literature will be supported by the data obtained through mosque images, in terms of concepts such as preference/liking, complexity and impressiveness variables makes a difference in the perception of mosque images. For this purpose, the data obtained through mosque visuals will be investigated in terms of the preference, complexity and impressiveness variables. Thus, it will also be determined whether architectural education makes a difference in perception of mosque images.

\section{MATERIAL and METHOD}

The mosques are the symbol of the second largest religion, Islamic religion, in the world and used as places of worship with different designs that are built differently according to the climate conditions, periods, countries and architectural trends within the geographical boundaries where the Islamic religion is spread. In this study, it has been aimed to determine the effects of mosques on the perceptual performance of architects and nonarchitects/laypersons. In the first phase of this study, Arslan and Ylldırım (2017) examined the effect of age, gender and education level differences on participants' evaluation of the same mosque visuals. In this study, the differences between perceptual evaluations of architects and non-architects will be evaluated. The choice of participants, digital photographs used in the study, the design of research study and statistical evaluation methods are explained below respectively.

50 architects and 50 non-architects participated in this study randomly selected from among the people living in the central settlement area of Konya. In this study, besides historic museums from the past, 16 different mosque examples built according to the modern architectural insights have been dealt with. Mosque samples from Turkey have been examined in three sub-groups. In the $1^{\text {st }}$ group, the mosques of the $10^{\text {th }}-14^{\text {th }}$ centuries, which are within the present-day borders of Turkey (Anatolia), representing the Seljuk architecture which was a trend created by the Seljuk Empire; in the $2^{\text {nd }}$ group, the examples from the Ottoman architecture, which was a created by the Ottoman Empire, which dominated a very wide area in the world including the territory of Turkey since the end of $14^{\text {th }}$ century until the $20^{\text {th }}$ century have been studied. In the $3^{\text {rd }}$ group, the new modern era mosques of the Republic of Turkey after the collapse of the Ottoman Empire have been examined. The only parameter in the selection of mosques is the construction periods. The digital photograph of the facade views of a total of 16 different mosques used in the survey study 
was manifolded in the sizes of $130 \times 180 \mathrm{~mm}^{2}$ colorful and high quality (600 dpi). The numerical distribution of the mosques divided into 3 groups is shown in Table 1 and the digital photographs of the mosques sorted according to periods are given in Figure 1.

Table 1. Numerical distribution of mosque

\begin{tabular}{|l|l|c|c|}
\hline \multicolumn{1}{|c|}{ Group } & Mosque Group Name & Historical Period & $\begin{array}{c}\text { Sample } \\
\text { Number }\end{array}$ \\
\hline 1. Group & Seljuk Architecture & $10-14$ centuries & 5 \\
\hline 2. Group & $\begin{array}{l}\text { Ottoman } \\
\text { Architecture }\end{array}$ & $14-20$ centuries & 5 \\
\hline 3. Group & $\begin{array}{l}\text { Republic Period of } \\
\text { Turkey Architecture }\end{array}$ & $20 \quad$ centuries - & 6 \\
\hline \multicolumn{2}{|c|}{ Total Mosque Number } & 16 \\
\hline
\end{tabular}

On the basis of research hypotheses, dependent variables were dealt with in two dimensions and these were measured using a detailed survey. The survey form used consisted of two parts: the first part asked for general information such as the age, gender, education and job of the participants. The second part consisted of a five-point semantic differential scale about participants' perceptual evaluations of the facade characteristics of the mosques. The participants then had to evaluate the importance of each of the bipolar adjective pairs on a 1-5 semantic differential scale where $1=$ beautiful and $5=$ ugly. The technique of altering the sets of items consisting of three different adjective pairs from positive to negative, as previously done by Berlyne (1974), Imamoglu (2000), Akalin-Baskaya and Yildirim (2007), Akalın et al. $(2009,2010)$ and Arslan and Ceylan (2012) was adopted to reduce the probability of respondents simply marking the scale on either end of the extremes. The semantic differentiation scale is not intended to measure only one dimension of the perceived space; it is an important scale enabling many qualities to be measured in one go and allowing objective assessment of subjective assessments. Survey data were obtained in about 2 months by face-to-face interviews at home and workplaces of participants in 2015. The surveys were applied to the participants at different times of the day including weekdays or weekends. The participants completed the survey in approximately 20 minutes. 


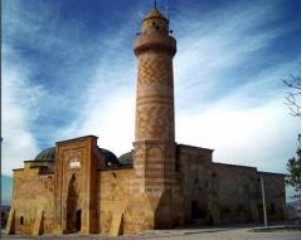

Alaeddin Mosque, NİĞDE,TURKEY

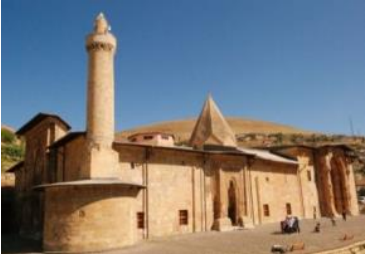

Divriği Ulu Mosque, SIVAS,TURKEY

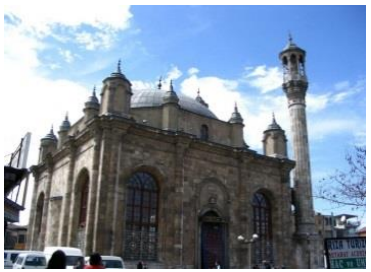

Aziziye Mosque, KONYA,TURKEY

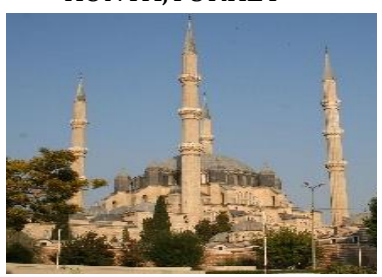

Selimiye Mosque, EDIRNE,TURKEY

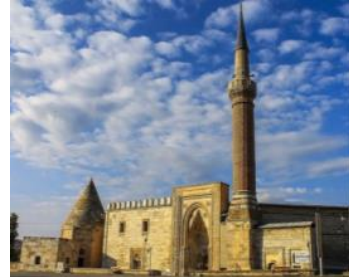

Eşrefoğlu Mosque, KONYA, TURKEY

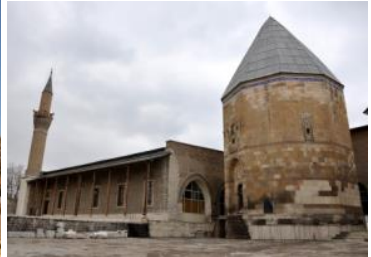

Alaeddin Mosque, KONYA TURKEY

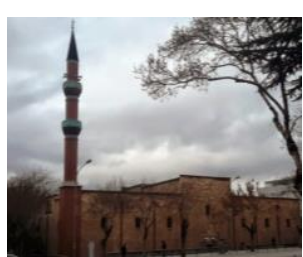

İplikçi Mosque, KONYA,TURKEY

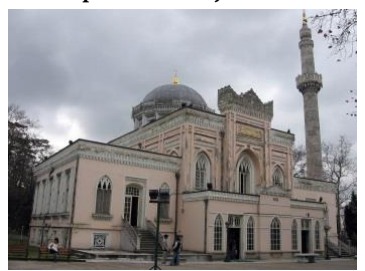

Yıldız Hamidiye Mosque, ISTANBUL, TURKEY

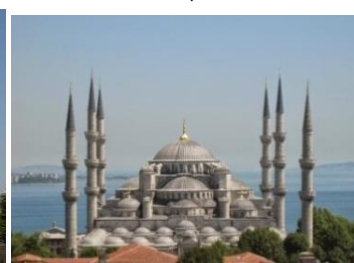

Sultan Ahmet Mosque, İSTANBUL, TURKEY

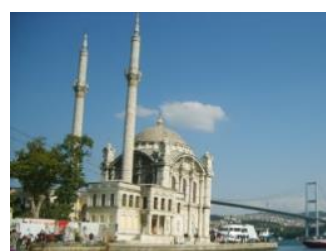

Ortaköy Mosque, ISTANBUL,TURKEY

Group 2 - Samples of Ottoman Architecture

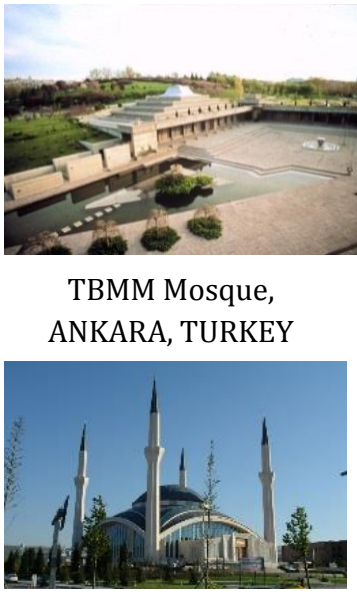

Ahmet Hamdi Akseki Mosque, ANKARA, TURKEY

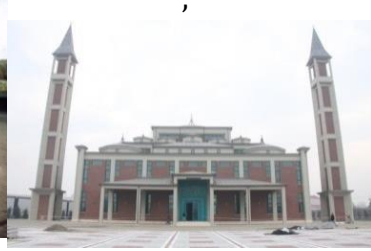

OSB Mosque, BURSA, TURKEY

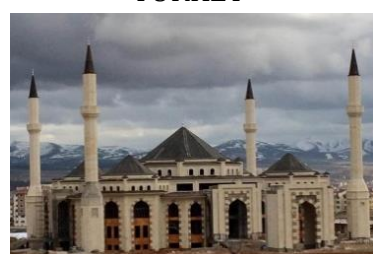

Dört Minareli Mosque, KIRŞEHIR, TURKEY

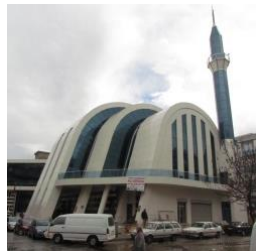

Gazi Emir Mosque, İZMIR, TURKEY

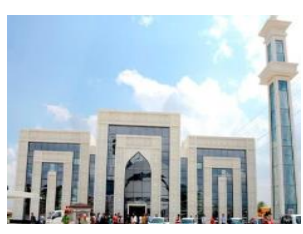

Sekine Hatun Mosque, KONYA, TURKEY classified according to the periods of the mosques (Arslan and Yıldırım, 2017)

\section{Group 3 - Samples of Republic period}


In this study, the participants' perceptual evaluations of the facades of the mosques were considered as "dependent variables". There are many factors that influence the participants' perceptions of facade features of the mosques. From these factors, "the mosques of different periods" and "job" were considered "independent variables". These two identified independent variables were grouped as; $\mathrm{X}_{1}$ : The facade features of the mosques (Seljuk period, Ottoman period and Republic period), $\mathrm{X}_{2}$ : Job (Architect and Non- Architect). Percentage values, arithmetic mean and standard deviations of the data obtained in the study were calculated and Cronbach Alpha reliability tests of data were performed. Single variance analysis (ANOVA) was performed to test whether the differences between dependent and independent variables were statistically significant at $\mathrm{P}<0.05$ level. To compare the significant means of the variance in the analysis, the data is presented in graphic form.

\section{RESULTS AND DISCUSSION}

In this study, the facade features of (Seljuk period, Ottoman period and Republic period) some important mosques from different periods were evaluated according to the adjective pairs of complexity, preference and impressiveness variables. Also, whether or not the general views of the mosques represent Islamic religion and their level of arousing curiosity were questioned. For this purpose, in the study, a total of 16 mosques were used, with at least the photographs of 5 mosques from each group. The results obtained from the participants with the help of a survey are given below, respectively.

The reliability of the semantic differential scale including perceptual evaluations of participants about facade features of the mosque was tested with Cronbach alpha and the results are given in Table 2. The Cronbach alpha reliability coefficient of all adjective pairs used in the study is 0.83 . In the previous studies, the scale coefficients over 0.70 were accepted reliable (Cronbach, 1951; Kaplan and Saccuzzo, 2009; Panayides, 2013). In this context, is scale was also found reliable.

Table 2. Results of reliability analysis of the dependent variables

\begin{tabular}{|l|l|c|c|}
\hline $\begin{array}{c}\text { Dependent } \\
\text { Variables }\end{array}$ & Scale Items & Item Reliability & $\begin{array}{c}\text { Scale } \\
\text { Reliability }\end{array}$ \\
\hline Preference & beautiful - ugly & 0.78 & \multirow{2}{*}{0.83} \\
\hline Complexity & simple - complex & 0.82 & \\
\cline { 1 - 2 } Impressiveness & $\begin{array}{l}\text { impressive } \\
\text { unimpressive }\end{array}$ & 0.70 & \\
\hline
\end{tabular}

Note: For each dependent variable, the scale reliability is provided. 
In this part, the differences between the perceptual evaluations of participants about the facade characteristics (Seljuk period, Ottoman period and Republic period) of the mosques according to the dependent variables were statistically tested. According to this, the mean and standard deviation values of dependent variables were determined in 3 groups (preference, complexity and impressiveness). The results are given in Table 3.

Table 3 shows that it is determined that differences among the perceptual evaluations of the facade attributes of the mosques varies according to the various professional status (architect and non-architect). From the evaluation of the means it can be seen that non-architect participants have a more positive perception of the facade attributes of the mosques for complexity variable than architect participants.

Table 3. Means and standard deviation values of the dependent variables according to professional status of participants

\begin{tabular}{|c|c|c|c|c|c|c|}
\hline \multirow{3}{*}{$\begin{array}{c}\text { Dependent } \\
\text { Variables }\end{array}$} & \multicolumn{4}{|c|}{ Professional Status } & \multirow{2}{*}{\multicolumn{2}{|c|}{ Total }} \\
\hline & \multicolumn{2}{|c|}{ Architect } & \multicolumn{2}{|c|}{ Non-Architect } & & \\
\hline & $\mathbf{M}^{\mathbf{a}}$ & SD & $\mathbf{M}$ & SD & $\mathbf{M}$ & SD \\
\hline Preference & 2.27 & 1.13 & 2.28 & 1.17 & 2.28 & 1.13 \\
\hline Complexity & 2.85 & 1.19 & 2.69 & 1.16 & 2.82 & 1.19 \\
\hline Impressiveness & 2.59 & 1.21 & 2.69 & 1.18 & 2.61 & 1.21 \\
\hline
\end{tabular}

Notes: M: Mean, SD: Standard Deviation. a: Variable means ranged from 1 to 5 , with higher numbers representing more negative responses.

The differences between the perceptions of facade attributes of the mosques in terms of professional status (architect and nonarchitect) were also tested using ANOVA (Table 4). According to the results given in Table 4, the differences between the dependent variables including the perceptions of the facades in terms of participants' professional status was found to be statistically significant (at a level of $\mathrm{p}<0.05$ ) for complexity variable. Consequently, it can be said that the differences between the participants' professional status have a significant influence on perceptual evaluations and participants from the nonarchitects evaluated mosque facades more positive than the architects. This result, which belongs to the complexity variable, was previously reported by Akalın et al. (2009). However, this result does not support the result of İmamoğlu (2000). As Imamoglu (2000) has mentioned, non-architecture students, in comparison to architecture students, in general rated house façades (both traditional and modern) as more complex, especially for the perceived maximum complexity level. Gifford et al (2000) has shown that architects and non-architects base their emotional assessments on almost entirely different sets of 
objective features, which as he suggests, help to explain why the aesthetic evaluations of both groups are virtually unrelated.

Table 4. ANOVA results of the dependent variables in terms of the professional status of participants

\begin{tabular}{|l|l|l|l|l|l|l|}
\hline \multicolumn{2}{|c|}{ Dependent Variables } & \multicolumn{1}{|c|}{$\begin{array}{c}\text { Sum of } \\
\text { Squares }\end{array}$} & \multicolumn{1}{|c|}{ df } & $\begin{array}{c}\text { Mean } \\
\text { Squares }\end{array}$ & \multicolumn{1}{|c|}{ F } & Results \\
\hline \multirow{3}{*}{ Preference } & Between Groups & 0.026 & 1 & 0.026 & 0.020 & $0.888 \mathrm{~ns}$ \\
\cline { 2 - 8 } & Within Groups & 3501.173 & 2698 & 1.298 & & \\
\cline { 2 - 8 } & Total & 3501.199 & 2699 & & & \\
\hline \multirow{3}{*}{ Impressiveness } & Between Groups & 11.148 & 1 & 11.148 & 7.843 & $0.005^{*}$ \\
\cline { 2 - 8 } & Within Groups & 3835.112 & 2698 & 1.421 & & \\
\cline { 2 - 8 } & Total & 3846.261 & 2699 & & & \\
\cline { 2 - 8 } & Between Groups & 4.208 & 1 & 4.208 & 2.867 & $0.091 \mathrm{~ns}$ \\
\cline { 2 - 8 } & Total Groups & 3959.885 & 2698 & 1.468 & & \\
\hline
\end{tabular}

Notes: F: F Value, df: Degree of freedom, ${ }^{*} \mathrm{p}<0.05$ is the level of significance, ns: not significant.

On the other hand, there was no statistically significant difference between the participants' evaluations of preference and impressiveness variables (at $\mathrm{p}<0.05$ level). This result supports the preference result of the previously published Imamoğlu (2000). The differences between participants' perceptions of the mosque facades for dependent variables (preference, complexity and impressiveness) depending on their professional status (architect and non-architect) are illustrated in Figure 2.

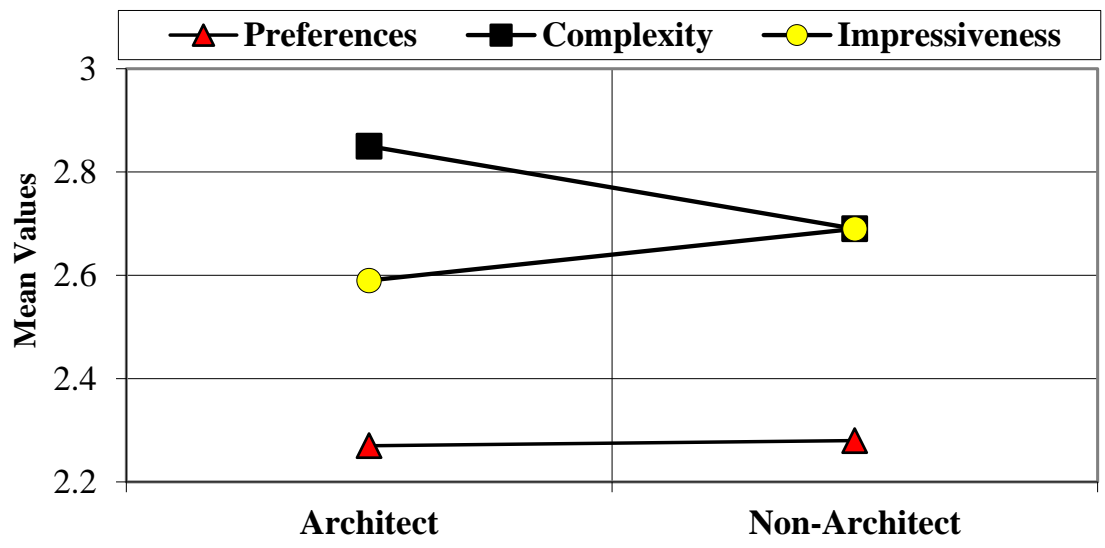

The effects of interactions between independent variables (participants' professional status and mosque groups) depending on participants' perceptions of facade features of the mosques for dependent variables (preference, complexity and impressiveness) were tested using the MANOVA. According to the results given in Table 5, the main effects (participants' professional status and mosque groups) and the two-way interactions for participants' professional status * mosque groups (at a level of $\mathrm{p}<0.05$ ) were found to be significant.
Figure 2. Effects of professional status of the participants to the dependent variables

Note: Variable means ranged from 1 to 5, with higher numbers representing more negative responses 
Table 5. MANOVA of the independent variables

\begin{tabular}{|l|c|c|c|c|c|}
\hline \multicolumn{1}{|c|}{$\begin{array}{c}\text { Independent } \\
\text { Variables }\end{array}$} & Value & F & df & Sig. & Result \\
\hline Professional Status & 0.008 & 4.385 & 3 & 0.004 & $P<0.01^{*}$ \\
\hline Mosque Groups & 0.290 & 90.016 & 6 & 0.000 & $P<0.01^{*}$ \\
\hline $\begin{array}{l}\text { Professional Status } \\
\text { * Mosque Groups }\end{array}$ & 0.009 & 2.270 & 6 & 0.034 & $P<0.05^{* *}$ \\
\hline
\end{tabular}

Notes: F: F value, df: Degree of freedom.

$* * \mathrm{p}<0.01$ and $* \mathrm{p}<0.05$ are the level of significance.

\section{CONCLUSION}

The followings have been aimed in this study: to determine the effect of the facade characteristics of the mosques of different periods on perceptual evaluations of people through mosque images; to compare the results obtained with respect to the variables of preference, complexity and impressiveness; to determine whether architectural education makes a difference in the perception of mosque images.

According to the results, the differences between the dependent variables including the perceptions of the facades in terms of participants' professional status was found to be statistically significant (at a level of $p<0.05$ ) for complexity variable. On the other hand, there was no statistically significant difference between the participants' evaluations of preference and impressiveness variables (at $\mathrm{p}<0.05$ level).

The study shows that the participant architects show a statistically more negative approach compared to those who are non-architects in the perceptual evaluations of the facades of the mosques for complexity variable. This result was previously reported by Akalın et al. (2009), but does not support the result published by Imamoglu (2000). These results may be due to the fact that the group of non-architect participating in the survey considered the religious structures more symbolically. Also, architects know the existence of more and more different buildings may have caused them to respond more positively than non-architects in different types of mosques.

\section{REFERENCES}

Akalin-Baskaya, A., \& Yildirim, K. (2007). Design of circulation axes in densely-used polyclinic waiting halls. Building and Environment, 42, 1743-175.

Akalin, A., Yildirim, K., Wilson, C. \& Kilicoglu, O. (2009). Architecture and engineering students' evaluations of 
house facades: Preference, complexity and impressiveness. Journal of Environmental Psychology, 29(1), 124-132.

Akalin, A., Yildirim, K., Wilson, C. \& Saylan, A. (2010). Users' evaluations of house façades: Preference, complexity and impressiveness. Open House International, 35(1), 57-65.

Arslan H.D. and Ylldırım K., (2017). "Perceptual Evaluations of Different Period Mosque Facades: Preference, Complexity, Impressiveness and Simulative" Megaron Journal, 12,4,511523.

Arslan, H.D., Ceylan M., (2012). "Judging Primary School Classroom Spaces Via ANN Model" Gazi University Journal of Science, 25, 1,

Baytin, C.. (1994). " An Approach to the Case of New Buildings in Historical Environments, An Applied Model for Istanbul, İstanbul Technical University, Graduate School of Natural and Applied Sciences, PhD Thesis, İstanbul.

Berlyne, D. E. (1974). Studies in the new experimental aesthetics. New York: Wiley.

Brown, G., Gifford, R. (2001). Architects Predict Lay Evaluations Of Large Contemporary Buildings: Whose Conceptual Properties?, Journal of Environmental Psychology, . 21, 9399.

Cronbach, L.J. (1951). Coefficient alpha and the internal structure of tests, Psychometrika, 16 (3): 297-334.

Crozier, J.B. (1974). Verbal and exploratory responses to sound sequences varying in uncertainty level

Devlin, K. \& Nasar, J.L. (1989). The beauty and the beast: Some preliminary comparisons of "high" versus "popular" residential architecture and public versus architect judgments of same. Journal of Environmental Psychology, 9(4), 333-344.

Dunn, J. V., Hayes, M. V. (2000). Social Inequality, Population Health, and Housing: A Study of two Vancouver Neighborhoods", Social Science \& Medicine, Vol. 51, No. 4, pp. 563-587.

Evans, G. W. (2003). The Built Environment and Mental Health, Journal of Urban Health: Bulletin of the New York Academy Medicine, 80, 4, 536-555.

Füeg, F. (1981). "Mimarinin Temelleri”, Çev: Kazmaoğlu, M., Yapı, No. 39, sf. 28-32, YEM Yayınları, İstanbul.

Gifford, R., Hine D. W., Müler-Clemm, W., Reynolds, D. J. and Shaw, K. T. (2000). Decoding Modern Architecture: A Lens Model Approach for Understanding the Aesthetic Differences of Architects and Laypersons, Environment and Behavior, Vol. 32, pp. 168-187.

Gifford, R., Hine, D. W., Clemm, W. M., Shaw, K. T. (2002). Why Architects and Laypersons Judge Buildings Differently: Cognitive Properties and Physical Bases, Journal of Architectural and Planning Research, Vol. 19, No. 2, pp. 131148.

Groat, L. (1982). Meaning in post-modern architecture: an examination using the multiple sorting task. Journal of Environmental Psychology, 2, 3-22. 
Hershberger, R. G. \& Cass, R. (1974). Predicting user re-sponses to buildings. In J. L. Nasar, (Ed.), Environmental Aesthetics: Theory, Research, and Applications. NewYork: Cambridge University Press, pp. 195-211.

Hershberger, R. G. (1969). A study of meaning and architecture. In J. L. Nasar, (Ed.), Environmental Aesthetics: Theory, Research, and Application. New York: Cambridge University Press, pp. 175-194.

Herzog, T. R., \& Shier, R. L. (2000). Complexity, age, and building preference. Environment and Behavior, 32, 557-575.

Imamoglu, C (2000). Complexity, preference and familiarity: architecture and nonarchitecture Turkish students' assessments of traditional and modern house facades. Journal of Environmental Psychology, 20, 5-16.

Kaplan, R.M. \& Saccuzzo, D.P. (2009). Psychological Testing Principles, Applications, and Issues. 7th Edition. (Belmont, CA.: Wadsworth)

Kaplan, S., Kaplan, R. \& Wendt, J.S. (1972). Rated preference and complexity for natural and urban visual material. Perception and Psychophysics, 12(4), 354-356.

Kobayash, K., Sato, M. (1992), Type Ia Supernova Progenitors, Environmental Effects and Cosmic Supernova Effects, Type Ia Supernova: Theory \& Cosmology, pp. 63-89.

Krier, R., (1993) "Architecture and Urban Design" Academy Editions.

Küller, R. (2002). The Influence of Light on Circarhythms in Humans, Journal of Physiological Anthropology and Applied Human Science, Vol. 21, pp. 87-91.

Nasar, J. L. (1983). Adult viewers' preferences in residential scenes: a study of the relationship of environmental attributes to preference. Environment and Behavior, 15, 589-614.

Nasar, J. L. (1989). Symbolic meaning of house styles. Environment and Behavior, 21, 235-257.

Noguchi, H., Sakaguchi, T. (1999). Effect of Illuminance and Color Temperature on Lowering of Physiological Activity, Applied Human Science Vol. 18, No. 4, pp. 117-123.

Panayides, P. (2013). "Coefficient alpha: interpret with caution", Europe's Journal of Psychology, Vol. 9 No. 4, pp. 687-696.

Stamps, A. E. (1991). Comparing preferences of neighbors and neighborhood design review board. Environment and Behavior, 23, 618-629.

Stamps, A. E. (2003). Advances in visual diversity and entropy. Environment and Planning B, Planning and Design, 30, 449463.

Tsunetsugu, Y., Miyazaki, Y., Sato, H. (2005). Visual Effects of İnterior Design in Actual-Size Living Rooms on Physiological Reponses, Building and Environment, Vol. 40, pp. 1341-1346.

Wohlwill, J. F. (1968). Amount of stimulus exploration and preference as differential functions of stimulus complexity. Perception and Psychophysics, 4, 307-312. 


\section{Resume}

Hatice Derya Arslan works at Necmettin Erbakan University, Department of Architecture, as an Dr.. She got her B. Sc., MSc and $P h D$ degrees at Faculty of Architecture of Selçuk University at 2000, 2003 and 2010, respectively. Since 2013 she has been worked as Dr. in Necmettin Erbakan University, Department of Architecture. She is also founder of the architecture department. Her current research interests are perceptional evaluation of space, planning, space analyses, sustainability.

Kemal Yıldirim, PhD, is a professor of furniture and interior design at Gazi University. His main research topic has been the analysis of interior space and user satisfaction in connection with the visual perception of space.

Esin Gülşeker works as architect. She got her B.Sc degree from Selcuk University at 2012. She has just graduated from MSc program of Necmettin Erbakan University Architecture Department with the thesis of sustainable school buildings in the MSc under supervisor of H.Derya Arslan. 